\title{
Human Resources Development and Sustainable African Development: A Reconsideration of Some Fundamental Issues
}

\author{
Paul Nwakpa \\ Department Of Educational Foundations \\ Faculty Of Education, Ebonyi State University, Abakaliki, Nigeria \\ Email: bropaulnwaoo [AT] gmail.com
}

\begin{abstract}
The ambition of this paper was to examine the role of human resources in sustainable African development. It argued that the nexus between human resources development and sustainable development cannot be over-emphasized. It observed that during colonial rule, the policy on human resources development was discriminatory to the disadvantage of Africans. It further argued that the place of intellectuals in the development of human resources could not be ignored as their role is a sacred one and blamed poor human resources development record in Africa on bad leadership. It lamented the inability of government to make good use of recommendations of intellectuals during seminars, workshops and conferences. The paper concluded that a holistic approach should be adopted which would place human beings at the centre of development and recommended among others that poverty should be reduced while people should be made to have access to education and health.
\end{abstract}

\section{INTRODUCTION}

The indispensability of human resources cannot be overemphasized as it is the centre or heart of any nation or organization. It is the engine or power-house that propels any nation or organization with clearly defined goals to be achieved. It is indisputable that know-how human talent is the most important asset of any industry or organization as it marshals available resources to achieve profit and to meet competition in the dynamic years ahead. Land as an important factor in production may be scarce or exorbitant to afford, but once it is available with good people around, it can be utilized profitably.

As rightly pointed out by Inyang and Akpama (2002), all the activities of any enterprise are initiated and determined by the persons who make up that institution, computers, plants, offices, automatic equipments and all else that a modern firm uses are unproductive without human effort and direction. It is in recognition of this fact that the Nigerian government over the years shifted attention to the development of its human resources by establishing educational institutions of various types and health centres throughout the country to train and develop its human resources.

This effort on the part of government has to some extent yielded fruits going by the caliber of people the nation has produced in various fields of endeavour. But the question to ask is, has the Nigerian government been able to effectively utilize these human resources for the growth and development of the nation? Has the Nigerian government been committed to effective use of recommendations of intellectuals during workshops, seminars and conferences in view of the fact that these academics are the producers of these human resources? It is the ambition of this paper to look at this and other fundamental issues relating to human resources development in Africa.

\section{THE CONCEPT OF HUMAN RESOURCES DEVELOPMENT}

The notion of human-centred development was first given formal impetus and intellectual motivation with the publication of the United Nations Development Programm's (UNDP's), Human Development Report (HDR) in 1990. Since this publication and subsequent ones, it has been popularly accepted that human development must be seen as a process of expanding human choice by enabling people to enjoy long, healthy and creative lives (Umoh, 2002).

Human resource development is not possible if humans are unhealthy or remain incapacitated by all types of diseases. Health indicators are therefore integral part of a vital set of human resource development. Africa has over the years been threatened by diseases such as malaria, tuberculosis and measles, HIV/AIDS and so on and so forth and consequently the continent cannot achieve effective human resources development. The shift in focus by government to more investment in human resources development is in recognition of the fact that healthy and well educated people are propellers of the economy.

The Khartoum Declaration of 1988 emphasized the need for effective human resources development. The Declaration stated emphatically that the human dimension is the sine-qua-non of economic recovery and warned that no structural adjustment programme or economic recovery programme should be formulated or implemented without taking 
into consideration detailed human and social priorities as there can be no real structural adjustment in the absence of the human imperative (Adedeji, 1990) corroborating the stand of the Khartoum Declaration of 1988, the Economic Commission for Africa's Ministerial Conference held in 1990 emphasized human focused approach to socio-economic recovery and development.

Human resources development is an attempt to make people more productive through improvement in their skills, education, nutrition, health and other social indices through adequate and proper investment. In his contribution, Bassey (1997) pointed out that the human resources of a country refer to the entire people of that country. This view cannot be ignored because every human being in a country including the unborn babies in the womb have some impacts on the political and socio-economic life of a nation in terms of government policies to cater for them while in the womb and after delivery. Subscribing to this view, Yesufu (2000) stated that the term human resources as the total population also constitute the totality of consumers for whom the economic bell tolls and whose welfare is the objective of pursuing economic development.

From an organizational or institutional point of view, Ndionm (1992) and Eziani (2002) separately pointed out that the human resources of an organization comprise of men and women, young and old who engage in the production of goods and services and who are the greatest asset of the organization. In his contribution, Eze (1995) stated that an organization consists of human beings who work together to achieve their own specific goals, and that those human beings who do things together to accomplish objectives constitute the human resources of the organization.

Manpower development is a field that is concerned with obtaining, organize and motivating the human resources required by enterprise and developing an organizational climate and management which will promote effective effort, cooperation and trust between all the people working in it and with helping the enterprise to meet its legal obligation and its social responsibilities towards its employees with regard to the conditions of work and quality of life provided for them (Obo and Mboto 2004). Human resources development is an indispensable factor in sustainable development. The strategy for human resources development concerns the two-fold objectives of building skills and productive employment for non-utilized manpower. Both have their roots in changes inherent in the development process and are related in part to education. Education is therefore a sound economic investment that raises the quality of life, improves health and productivity, increases individual's access to paid employment and human often facilitates social and political participation (Olanyi and Adam, 2002).

When a country plans its manpower well and follows it up with a systematic development of its human resources the possibility of coming closer to the achievement of democracy, good governance and the solution of some social problems. When human resources are developed in all aspects, our democracy will develop, our security system will develop and indeed all our institutions will develop. Human resources development is the process of increasing knowledge, skills and the capacities of the workers in an organization. Politically, human resources development prepares people for effective participation in political processes in a democracy. It is the extent to which human resources of a nation are developed that determines the level of development of that nation in all aspects because it is vanity to attempt to develop the nation without first developing the man who is "the measure of all things".

\section{Human Resources Development in Nigeria}

The genesis of human resources development effort in Nigeria could be traced to the emergence of the concept of the family. In predominantly underdeveloped social formations like Nigeria, the head of the family, in this case the father was at the head of the economic affairs of the family with the help of the wife or wives and children (Obo and Mboto, 2004). The father as head of the family did not have to pay his wives and children for their services but to ensure they were well-fed and clothed. In fact, the overall performance of the family was contingent upon the ability of the head of the family to adequately cater for the needs of members of the family, but during colonial rule, Nigeria witnessed high level of underdevelopment of her human resources. This was as a result of the nature of colonialism and what it sought to achieve which included amassing wealth and controlling the commanding height of the nation's economy. This would have been difficult to achieve if human resources of Nigeria well trained and developed.

Since the main objective of British colonial rule was to explore and exploit both human and material resources of Nigeria for their personal interest, colonial polices were geared toward realizing this goal. The colonialists knew that if human resources of Nigeria were effectively developed, it could work again their interests as they would be armed with knowledge which could be detrimental to actualizing their dreams. But since the colonial powers needed auxiliary staff to assist them in performing minor functions, they recruited few Nigerians and trained them to function as interpreters, court clerks, mail distributors, messengers as well as to perform other minor and degrading functions which portrayed Nigerians as inferior to the British colonialists. Nigerians were not permitted to undergo the type of training or be educated along such lines that would enhance the overall development of the individual. The British government totally worked against this.

The negative effect of the British selfish policy on human resources development of Nigerians was much felt after independence as Nigeria lacked the requisite manpower to serve the new independent state. To bridge the lacuna 
that existed, a Nigerianization commission was set up with the specific task of speeding up the supply of trained indigenous manpower to the service. With the publication of the final report of the Parliamentary Committee on the Nigerianization of the public service in 1960, the Standing Committee on Training and the Nigerianization office came into being as the Federal Government's Central Authorities responsible for training matters. These two bodies were to provide general supervising control and various training systems as may be possible.

Consequent upon the above disposition of government, it sought the assistance of the Institute of Administration of the University of Ife now the Obafemi Awolowo University, Ile lfe. A survey was conducted on the training needs of the Federal Civil Service. The exercise was carried out by C. P. Wolle and it revealed among other things that there was need to urgently provide a systematic and regular programme for the development of civil servants of all cadres. The government white paper on the Wolle's report could be regarded as the first formal definitive guidelines on manpower or human resources development in the Federal Civil Service of Nigeria (Bur, 1992).

South Africa under white minority rule was equally confronted with this ugly situation. When Nelson Mandella became the first black President of South African, he lamented that even though they have be granted independence, they lacked capable indigenous hands to run the system. The British colonial policy of segregation in South Africa did not offer opportunity for indigenous South Africans to be properly educated and trained especially along such lines that could have made them fill those positions that were vacant when the white colonialists finally left. Man-power development in South Africa before independence was seriously stifled and the aftermath could best be imagined.

\section{African Intellectuals and Human Resources Development}

Over the years, African intellectuals have made enormous contributions to the development of our human resources for sustainable development of the continent. This they have done through combined strategies of imparting knowledge to students in all fields of learning and through workshops, conferences, seminars organized by government, individuals, organizations and institutions of learning across the continent of Africa. However, the lofty efforts of these intellectuals have always seemed practically unnoticed because of the inability on the part of various governments in power to make good use of products of these intellectuals and their recommendations at various conferences, seminars and workshops which are vividly captured in local and international journals as well, in the print and electronic media.

As rightly pointed out by Soyinka (2010), the only function that can be demanded of the intellectual is the development of the human resource. According him, the expansion of the human mental horizon in every direction without limitation and the readiness to debate and justify his or her vision within the context of a comprehensive development of the human personality is precisely what constitutes the near-sacred mission of the intellectual. The type of nation or country that we want and hope for, a country of peace, free from corruption, a country of constructive development in all aspects does not begin with government, with statesmen or organizations, but rather with the enlightenment and development of the individual. The mandatory and sacred mission of the intellectual in educational institutions therefore, is to develop the hearts and minds of students; to provide society with artisans, technicians, knowledgeable parents, teachers, leaders, public servants and professionals in all fields of human endeavour and to build character and integrity in these students who in turn will bring their wealth of knowledge to bear on the development of the society thus bringing to society the benefits of their learning. This is indeed a great responsibility on the part of intellectuals and academic institutions of learning because from enlightened and intelligent individuals will emerge progressive leaders who will contribute their quota to sustainable development. Education therefore, is without doubt the principal ingredient in the development of any nation.

\section{Leadership and Human Resources Development in Africa}

Bad leadership to a large extent has contributed to poor human resources development record in Africa. As observed by Akpan (1999) African leaders do not have clear-cut principles on how to govern their countries, and neither are they ready to accept certain principles and rules that are essential for a worthwhile democracy.

Sit-tightism in African States has also contributed to lack of commitment by African leaders to human resources development in Africa. Most African leaders for fear of losing their positions prefer to maintain the statuesque and permit their citizens to wallow in ignorance, they allocate very little resources to the education sector and use draconian laws and all sorts of threats both manifest and latent to debar intellectuals from executing their sacred mandate of imparting the right kind of knowledge to the citizens. Corruption as a cankerworm has eaten deep into the fabric of most African States. Most African leaders have amassed enormous wealth through dubious means and siphoned same to their foreign bank accounts for selfish interest. These are public resources which would have been used for the development of human resources. As observed by Anyanwu in Akpan (2012), most African leaders are power-drunk to a point of madness and are prepared to do anything if only to remain in power. Consequently, this has produced short-sighted leaders who have become permanent landlord in most States Houses in Africa. 


\section{Human Resources and Sustainable Development}

It cannot be disputed that a society or nation cannot exist without the people. It is the people that make up a nation and determine the wealth and development of any nation. Thus, for any nation to attain excellence in governance, it must give serious consideration to the development of its human resources. The experience during the early years of independence pointed to the fact that economic growth alone could neither guarantee nor ensured that the benefits of growth would improve the well-being of the citizenry. Thus, a new approach was required which would place human beings at the centre of development and at the core of the social and economic policies to be made if Africa was to achieve sustainable development.

Sustainable development is the development that could meet the needs of the present without compromising the ability of future generations to meet their own needs. Complexity surrounds the task of developing quality manpower for sustainable development, thus the need for the private sector to be involved especially in the areas of provision of Onthe-job training, establishment of foundations in the universities sponsoring particular management programmes in higher institutions of learning and research (Eburajolo 2006).

\section{CONCLUSION}

Human resources is a fundamental factor in sustainable national development. Investment in development and training of human resources is a worthwhile investment which will bring enormous returns. Investment in this fundamental factor of production has both qualitative and quantitative dimensions in the sense that human capital formation includes not only expenditure for education and training, but also the development of the right attitude towards productive activity (Asiegbu, 1992). The challenges of developing human resource for sustainable development is a serious business and cannot be left to chance. It must be approached from a holistic angle. As observed elsewhere in this paper, the Nigerian government concentrated only on economic growth during the early years of independence and this was not a guarantee that the benefits of growth would improve the well-being of the citizenry, thus, a new approach was required. This new approach was the adoption of a holistic approach which involved placing human beings at the centre of development.

\section{RECOMMENDATIONS}

1. Absolute poverty is very high in most African countries. For sustainable development to be achieved, poverty must be exterminated or at least reduced to minimal level. Poverty has very serious negative effect on a nation's human resources.

2. The government should generate employment for its teaming population of unemployed men and women. This is because if job creation rate is able to pace with the school outputs, impediments to human resources development would be removed.

3. Education is very critical to human resources development. High quality and market-relevant education is capable of offering genuine solution to most economic problems ranging from poverty eradication to population control. Formal education at all levels offers a foundation for knowledge accumulation and skill formation through on-the-job and out-of-the job training. For Africa to achieve the goal of sustainable development, it must show total commitment to education at all levels.

4. Women empowerment should he considered as a priority. This is necessary because women play an important role, directly or indirectly in various ways. Their contribution is very critical for the success of achieving the goals of human resources development (Umoh 2002).

5. The government should do everything to improve the health-care system. Prevalence of diseases is to a large extent a function of environmental sanitation, including availability of water supply and health-care personnel.

6. Recommendations of intellectuals during seminars, workshops and conferences should be implemented by government for practical and effective results and employment should be based on merit to encourage hardwork by students in institutions of learning.

\section{REFERENCES}

- Adedeji, A. S. (1990). The human dimension of Africa 's persistent economic crisis. United Nations Economic Commission for Africa: Hans Zell Publishers.

- Akpama, A. M. \& Inyang, B. J. (2002). Personnel management practice in Nigeria. Calabar: Merb Business Centre.

- Akpan, F. (1999). Leadership pathology and democratic experiment in Africa; Calabar: Journal of Politics and Administration. 1 (1).

- Akpan, 1. E. \& Akpan, 0. F. (2012). The challenges of African - America presidency to the stability of democracy in Africa. Journal of Pristine 5 (1) 92-100.

- Asiegbu, .1. U. (1992). Human resources development and utilization in Yahaya, A. D. and Akinyele, C. I. (eds.) 1-luinan resources development and utilization: Proceedings of the Conference on Human Resources Development and Utilization Policy. Badagry: (ASCON). 
- Bassey, C. O. (1997). The state and economy in Nigeria. In G. 0. Ozumba (ed.). Nigeria: Government and Politics. Aba: A. A. Industries, Printing and Publishing Division.

- Bur, A. (1992). The case for human resources development and utilization policy for Nigeria. In Yahaya, A. D. and Akinyele, C. I. (eds.) Human resources development and utilization: Policies and issues, Badagry: (ASCON).

- Eburajolo (2006). Building quality manpower for sustainable development. Journal of Nigerian Institute of Management (NIM) Chartered. 42 (1).

- Eze, N. (1 995). Human resources management in Africa: Problems and solutions. Lagos: Zoniex.

- Eziani, E. O. (2002). Basic elements for effective human resources management in local government system in Nigeria. In Eziani, E. 0. and Nwankwo, B. C. (eds.) Human resources management in local government system in Nigeria. Nsukka: A. P. Express.

- Ndiomu, C. B. (1992). Human resources development and utilization in the armed forces. In Yahaya, A. D. and Akinyele, C. 1. (eds.) Human resources development and utilization: Policies and issues. Badagry: (ASCON).

- Obo, U. B. \& Mboto, W. N. (2004). The role of human resources development in societal transformation in Nigeria. Nigeria Journal of Social and Development issues, 4(1).

- Olaniyi, O. \& Adam, J. A. (2003). Public expenditure and human development in Nigeria. Proceedings of Annual Conference on Human Resources Development in Africa. Ibadan: Nigerian Economic Society (NES).

- Soyinka, W, (2010). The role of intellectuals in development. The Nation Newspaper, October 26, 2010, 1-2.

- Umob, J. U. (2002). Human development in Africa: An overview. Proceedings of Annual conference on Human Resource Development in Africa. Ibadan: the Nigerian Economic Society (NES).

- Yesufu, T. M. (2000). The human factor in national development. Ibadan: Spectrum Books. 